\title{
Digitalization in German family firms - some preliminary insights
}

\begin{abstract}
Currently, digitalization is a key topic among firms. This paper addresses this topic in the case of German family firms. German family firms have been internationally recognized already for a long time to be at the same time very innovative but also acting very secretly. Therefore it is not surprising that prior literature on this topic is between scarce to inexistent even though literature on digitalization and SME's in general is widespread. The key question addressed in this paper is how German family firms try to face the challenge of the digital transformation. To provide some suggestions, we relate in an explorative and theorizing essay current evidence from literature on digitalization to key characteristics of German family firms and to insights we have gained in our personal relations to German family firms and their networks. We find indications that the digital transformation touches the heart of those firms as in the light of the new technological opportunities, key values such as innovation, secrecy, specialization on a niche and customer orientation might be in need to be redefined. As a result, starting from the German case we outline challenges and opportunities for family firms that might go far beyond the German case and point to fruitful areas for future research on family firms.
\end{abstract}

Keywords: Agile Organization; Digitalization; Digital Transformation; Family Business; Family Firm; Spinnovation; Digital Branding

Corresponding author: e-mail: sven.cravotta@srh.de

Received 08 Sept 2018 - Accepted 09 Nov 2018

This is an Open Access article distributed under the terms of the Creative Commons Attribution-Non-Commercial-No Derivatives License (http://creativecommons.org/licenses/by-nc-nd/4.0/), which permits non-comercial re-use and distribution, provided the original work is properly cited, and is not altered or transformed in any way. 


\section{Introduction}

Family businesses are the backbone not only in the DACH region ${ }^{\mathbf{1}}$ (Simon 2007, 40) but in the economies of many European countries (European Commission 2016). The economic importance of these companies is undisputed: in 2016, family-controlled companies compared to all active non-public companies accounted for $91 \%$; furthermore, they were responsible for a share in total employment in the private sector of $57 \%$ and a share in total turnover of $55 \%$ (Stiftung Familienunternehmen 2017, 2).

Taking family firms in a German context as an object of scrutiny is particularly interesting because the cultural background of Germany is well-known to stand for two aspects that are at the one end of two extremes: secrecy and dedication (e.g. Grottke et al. 2016a). Such values seem well to contrast with attributes such as transparency and flexibility that are commonly attributed to the Anglo-Saxon area (e.g. Gray 1988; Nobes 1998). Such values have led to the corresponding and internationally well-known description of the most salient German family firms as 'hidden champions' (Simon 2007) where the first word is a consequence of secrecy while the second is a derivative of dedication.

At the moment digitalization has become a buzzword in Germany. Digitalization can be understood in two ways: One way describes the technical process of converting analog signals into a digital form (Legner et al. 2017). This is accompanied by a dematerialization of information, a separation which decouples information from its physical carriers and allows for their digital storage. The second way in which this term is used consists in the multifaceted way in which socio-technical phenomena and the process of adopting and using digital technologies take place in another individual, organizational and social context (Legner et al. 2017). Hardly

\footnotetext{
${ }^{1}$ The DACH region includes Germany, Austria and Switzerland.
} 
any company in this country (and probably worldwide) can ignore the fact that at the moment all businesses are going through a digital transformation of their own business models. This also applies to family businesses.

In this paper, we present some insights with respect to central dimensions of the digital transformation and of the use of digital technologies from the perspective of family businesses. We do this by taking the characteristic features as well as the special opportunities offered to and risks to be faced by German family businesses in general as a starting point to develop a theoretical model that allows for identifying factors, that are widely discussed during the digital transformation. Given the strategic importance and the characteristics of German family firms to be hidden, in contrast to general literature on digitalization (e.g. Grottke and Boll 2018; Demary et al. 2016 among others), literature as well as empirical evidence on this topic is very scarce. The paper relies therefore on three sources: our own studies (e.g. Grottke and Boll 2018), digitalization cases in general that stem from family firms (Purs-Pardigol and Kehren 2018; Lichtner and Kinkel 2018) and our personal numerous anecdotal evidences from managers and owners of family firms that we have accumulated during the last years. From this material we extract what can be related to the specific characteristics of family firms, neglect what is not specific for digitalization in particularly family firms and theorize why certain elements of the digital transformation might fundamentally change the way in which German family firms carry out their business.

Our contribution in this respect is twofold. Theoretically our paper offers some indications that German family firms will take a different route through digitalization than other firms which might be interesting for family firms and other firms alike. Practical implications of our paper might be seen in the implications which - if they are correct - can help mid-size family 
businesses to face the rapid and extreme changes that arise with the digital transformation. While we recognize that due to the peculiarities of each family firm each firm will have to find its own way, we hope thus to assist to a certain degree by inspiring decision makers in those family firms.

The remainder of this paper unfolds as follows: First of all, the specific features of already existing German family businesses are discussed, by making reference to their quantitative and qualitative characteristics and by deriving a theoretical framework for family firms from those characteristics. Based on this framework, we outline why dealing with the digital transformation for family businesses is different from discussing digital transformation for startups and provide an overview which aspects of the digital transformation might be related to the framework and in which direction they change the framework. Then changes occurring with respect to six dimensions of digitalization are discussed that offer a relationship to family businesses: agile collaboration, expedient entrepreneurial family organization, spinnovation, digital branding and digital production in family businesses, and networking and collaboration between family businesses. A short summary and an outlook on future research opportunities arising from the preliminary insights of this paper conclude.

\section{Characteristics of family businesses and German family businesses}

When introducing characteristics of a family business, two starting points can be offered. One starting point might be to take recourse to the fact that family businesses can be described by their differencia specifica, that is, their characteristic that a family is behind the company and

that the firm can be significantly influenced by this family (Wittener Institut für Familienunternehmen 2018). Quantitatively, a significant influence requires a minimum of an equity investment held by the family which exceeds $25 \%$ (Cravotta 2013, 37-38). What is not 
necessary is an owner-manager. The decisive influence can be exercised also by the supervisory body (supervisory board or advisory board) (Cravotta 2013, 61-62; Wittener Institut für Familienunternehmen 2018). In consequence, family businesses can be managed by salaried managers, too (Cravotta 2010, 1; Cravotta 2013, 18; Cravotta 2014, 5).

Following qualitative characterizations of family businesses that can commonly be found in the literature, e.g. in Becker et al. (2008), Cravotta (2013), Hiebl (2012), Schlippe et al. (2008) and many others, three derivatives of family businesses can be identified. On the one hand, the family tends to transfer a more human, more informal and therefore more flexible element to the company. On the other hand, a family usually operates a company not only for economic purposes, but also for content-related reasons or the vision of a given owner. As a result, we typically find that family businesses maintain close relationships with customers whose problems are resolved accurately. Third, unlike a capital market-oriented firm, a family cannot easily raise equity as equity is limited more or less to the amount available from family members. This involves that the family firm tends to be less capital intensive than large corporations.

When we ask for the specifically German aspect in family firms three aspects stand out. First, the German business culture has been characterized by a tendency towards content related obsession or dedication that takes a focus on the long-term effect and corrects and optimizes issues even then when this might have negative consequences in a short-term perspective (Ahrens 1997). Second, there is a ubiquitous tendency of German ("hidden") family firms to secrecy (Grottke et al. 2016a). Third, there is a culture of competition and performance in business that understands businesses as a successful discovery procedure of better products, 
services and procedures and that therefore is very innovative but at the same time draws strong frontiers between a firm and those that are outside the firm (Grottke 2011).

Together the characteristics of family firms and the German context explain the worldwide known German family firms that have been characterized as "hidden champions" and it explains why those very successful German family firms have certain criteria in common: an obsession, shared with like-minded employees, focusing, setting standards, and customer orientation (Simon 2007).

The theoretical framework which emerges from all the aforementioned aspects is outlined in the following picture, in which the framework puts the aforesaid in a nutshell and demonstrates how German culture and family firm characteristics interact with and complement each other.

Figure 1. Theoretical Framework of the characteristics of German family firms

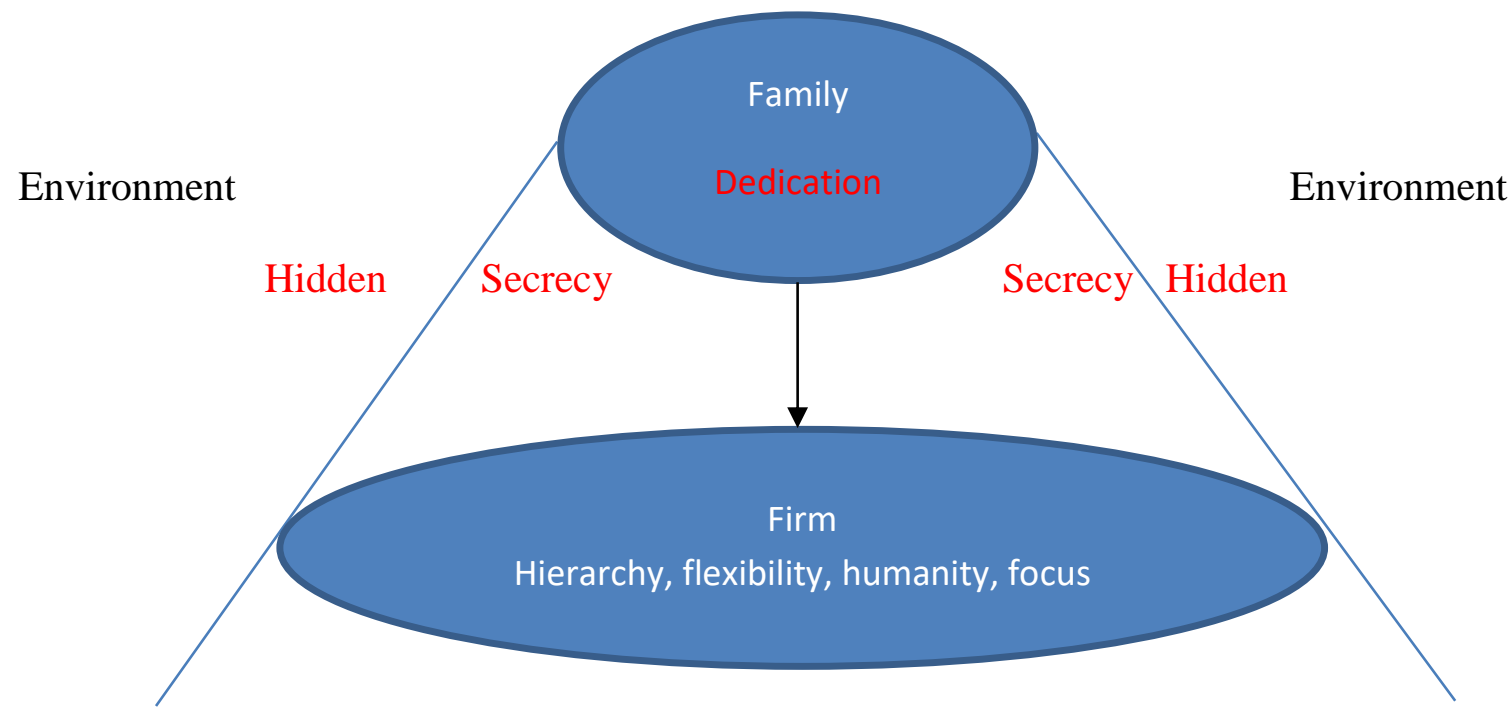

Customer orientation

Source: own illustration. 


\section{Special challenges of digitalization for German family businesses}

Why does digitalization involve specific challenges for German family businesses? This can be quickly understood by analyzing how main changes in digitalization can be related to the characteristics of German family businesses.

One challenge for family firms in general consists in the fact that the geographical and temporal independence which arises from virtual reality data can partially contrast with the limited resources and regional roots that lead to a forced focus of family businesses. For example, a family business which is involved in digital brand management will hardly diffuse new products by investing billions in order to flood the entire virtual space with information on their new products taking into account cultural peculiarities of all regions in the world from which inquiries about their own product now start to be requested in the virtual space. This does also set a challenge based on the so-called innovator's dilemma of disruptive innovations (Christensen 1997). It becomes increasingly clear that even today's world market leaders with brilliant products may be threatened by new, seemingly harmless, technologically and initially far inferior products. Examples are numerous: the Nikon camera of photos that was largely replaced by the smartphone, the metronome that was replaced by the Metronom-App, the physical key that is increasingly replaced by a kind of QR code. And so eventually whole industries and traditional companies disappear - a real danger, in particular for highly specialized family businesses, which are naturally forced to focus.

Another challenge consists often in the hierarchical structure of family businesses. Such firms have often a boss at the top, which characterizes the company through its charisma. This together with the ubiquitous tendency of ("hidden") family firms to secrecy (Grottke et al. 2016a) stands in stark contrast to the extensive and steadily increasing digital traces that lead 
to information overload for individuals and transparency of individual mistakes on the one hand and the increasing volatility, uncertainty, complexity and ambiguity on the other hand, that rather than individual decisions force to delegate decision making and to empower employees to take the best decisions.

A further challenge is that, in turn, digitalization puts new levels of human-machine automation at work, which makes many of today's jobs superfluous. Additive procedures such as rapid manufacturing and "mass customization" indicate that niches that were traditionally occupied by family businesses could in future also be filled by financially strong large companies.

Finally, comprehensive networking means that changes, both positive and negative, spread faster and that individual companies are barely able to operate in isolation from the digital world and from other companies. This is something which contrasts with the intention of many entrepreneurs in family businesses which is to be free from dependencies to act based on the own free will. In other words, typical characteristics of German family firms are under attack from different aspects of digitalization.

Figure 2. Theoretical Framework of the challenges for German family firms arising from digitalization

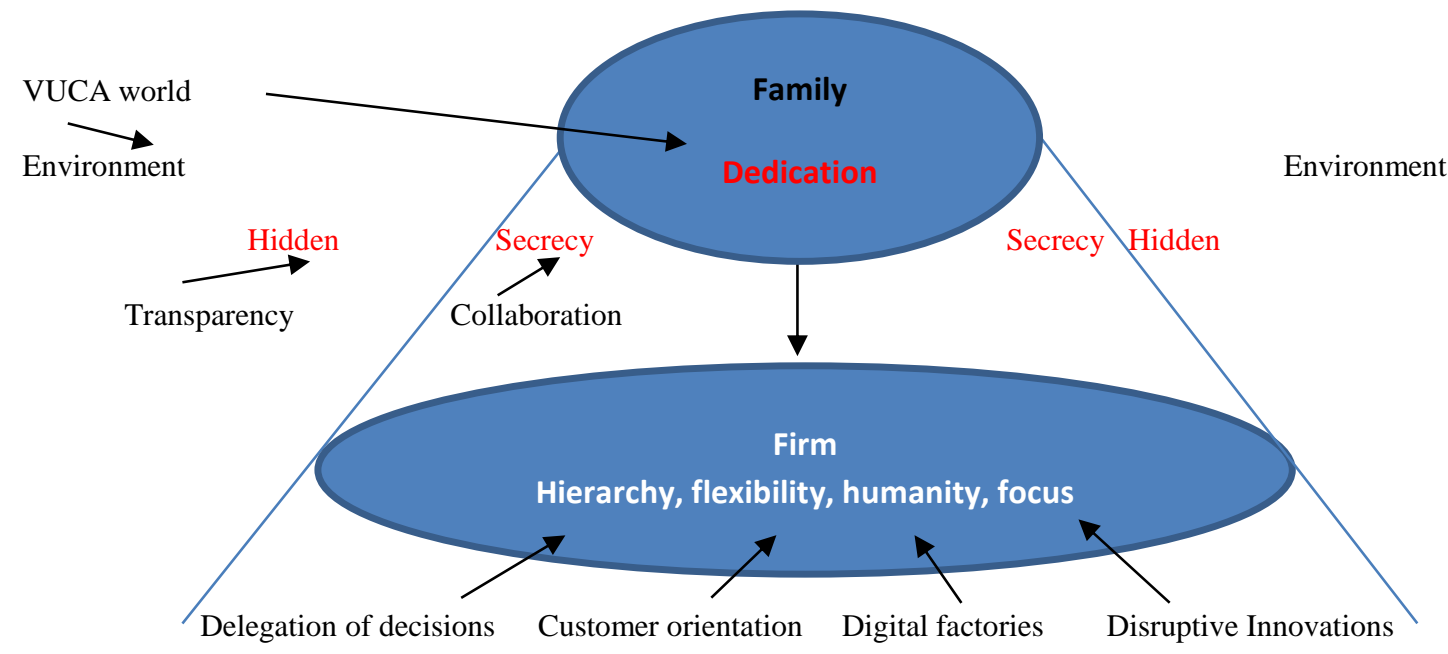

Source: own illustration 
How and why do family firms react or are recommended to react exactly in the way to those challenges as it can be observed in practice in Germany at the moment? In the following we provide an answer to this question. To this purpose, we group our empirical observations around six dimensions and theorize why German family firms experiment with exactly those changes.

\section{Dimensions of the reactions to digitalization by German family businesses}

How could family businesses react to these changes? To understand why this question is in need to be answered with a specific focus on the peculiarities of family firms it is necessary to carve out first why traditional family businesses in Europe, especially in Germany, cannot be equated with the startups in the Silicon Valley.

The key difference to startups consists in family businesses having been knowing their market for decades or even centuries (e.g. Simon 2007). Thus, they have a not inconsiderable wealth of experience on the one hand, which allows them to avoid unmanageable strategic options right from the beginning and to save much time and money that otherwise would be wasted in unnecessary trials. Conversely, startups in the Silicon Valley can accumulate capital resources that allow them to establish themselves quickly. By making use of a marketing budget that amounts to a multiple of the annual revenue, a company can rapidly become known in the virtual space all over the world and learn from its customers e.g. by making use of the measurebuild-learn-concept of the lean startup approach (Ries 2011; Cravotta et al. 2018a). But what can be a sensible way of dealing with digitalization of family firms? Robert Obermaier from the University of Passau, one of the leading German researchers on Industry 4.0 and digitalization, pragmatically took this as follows: Family businesses need to ask themselves which strategic decisions made today could increase the potential for new future decisions 
(Obermaier 2018). Below we discuss some interesting aspects in key dimensions of which we believe that they might have such a potential.

\subsection{Dimension agility and German family businesses}

One way that is discussed for increasing the productivity, adaptivity and pace of the highly human capital-oriented family firms in an age of digitalization consists in making use of the principles of agile organizations. This is a way which for example the German consulting firm Kyona proposes as a particularly suitable solution for family firms (Borg and Hill 2018). The basic idea is that the hierarchical structures of German family firms are too slow for a highly dynamically developing world. However, one could argue against this solution that hierarchies allowed for the dedication to a concrete idea which is typical for German family firms as hierarchy permits to be focused consistently across the family firm. Therefore, it is indispensable to decentralize. For this reason, the company management needs to replace concrete goals with a blurred vision; instead of a rigid planning, an increasingly adaptive roadmap takes into account already existing and in real time accruing experiences. Instead of personal communication, topic-related communication is preferred. Indeed, an agile family business gets rid of many problems such as the exploding email accounts of executives in family businesses. At the same time, however, dedication of the owner to his vision needs to be replaced by dedication to the vision of the owner of the employees. The digitalization project of the German family firm Rieber which reunited his employees around his vision to develop a way to verify the durability and health quality of food during an entire supply chain at a very low price is a case in point (Purps-Pardigol and Kehren 2018).

Moreover, agile organizations ensure that decisions can be made quickly and flexibly through their decentralization of decisions and through their empowering employees to make decisions. 
It also ensures that all talents and abilities are used by individuals, not just those provided in the job description. Imagine an employee to be comparable to cookie jar filled with various gemstones under a thin layer of grey stones. From this viewpoint it seems to be pure waste if the employee prefers to make use of his gems in the small animal breeder club or elsewhere but not at work, just because the family owner has only the grey stones in view.

Greater freedom for employees also ensures that market results are quickly absorbed by employees that act as sensors at the market. And the approach is particularly suited to raise the potential of ideas arising from interdisciplinary interaction and work.

The approach of agile organizations is not as alien as it might seem at first to family businesses. It has always been the case that in family-owned businesses humanity and informal communication have quickly transported the knowledge of employees through the hierarchy. The aspect which is new consists in avoiding the hierarchic structure and in the owner-manager changing from deciding to empowering decisions of the employees.

Furthermore, the hidden champions among family businesses have always been obsessed with a vision rather than with rigid planning. In this respect, changes to an agile organization should not be a disruptive innovation at all, but rather a natural development of existing ones, avoiding overburdening the entrepreneurial family and the executives. One risk of this organization might consist in the fact that in an agile organization, employees become much more important and less replaceable than before. However, at least good family firms are commonly known to suffer very little fluctuation within their work force. As we would expect the approach seems to spread empirically among family firms. In the study by Lichtner and Kinkel (2018), half of the 193 surveyed family businesses already use this approach. 


\subsection{Dimension expedient entrepreneurial family organization}

Since in a family business the peculiarity compared to other forms of business consists in the influence of the owner family which normally gives a family business a special economic stability, the question arises what might happen when digitalization leads to the occurrence of a VUCA world. One important aspect is that the owner family must always remain able to act and to make well-informed decisions. Therefore, the owner family (and not just the family business) needs to organize itself in a way so that it can meet the challenges of digitalization. Haftlmeier-Seiffert and Cravotta (2018) in their empirical analysis of German family firms speak here of the requirement of an expedient entrepreneurial family organization that follows the so-called Chameleon Model.

This model shows that different forms of organization are latent in entrepreneurial families. These are used flexibly, depending on what is expedient in order to arrive at decisions that are quickly viable; that is, the entrepreneurial family organization changes its explicit organizational form like a chameleon that changes its color. Exactly this property is just as helpful to transport not only the organizational form, but also the knowledge necessary to solve business challenges. Our experience from interviews with well-known German family entrepreneurs showed exactly this. For example, members of the entrepreneurial family who are scattered around the world feel often a need to transfer novel knowledge considered to be relevant to decision makers and outside family business managers to ensure that the decision makers in a family business are always well-informed about the challenges that are relevant to it. Such networks which can comprise up to hundreds of people in influential and informed positions can make a difference to the quality of decisions taken in the family firm. 


\subsection{Dimension permanent spinnovation}

Being limited in the resources family businesses had always to concentrate, to focus and to specialize. In an era of digitalization, however, disruptive innovations start to occur at a beforehand unknown pace. How this continuing focus on specialization as a hidden champion can be transferred to the age of digitalization is demonstrated by Venter and Friedrich (2017). The goal of the authors is to escape from the currently ubiquitously prevailing price competition. The means they propose in this context consist of a trias of a specialization in a complex problem on the one hand, innovation on the other hand, and, finally, a bottleneck or compulsory requirement of a group in need of the solution of this complex problem. In other words, it is important to innovate exactly at a place where a real need exists and then to specialize in the solution of this need as well as to stand out with respect to this solution. The authors emphasize that such needs are identified through extensive ethnographic analysis of the bottleneck (for example in the form of intensive interviews with customers who have quit recently). Most important might be that in times of disruptive innovations it becomes important not to address only one problem from one perspective but to choose deliberately a multiperspective and multichannel approach to complex problems. This involves, for example, not only trying to solve the problems of existing customers but to analyze whether there might be new types of future customers that have not come to mind so far. Such an approach is especially important as substitution in the era of digitalization can arise from many sides. The innovation to solve problems identified as bottlenecks is therefore addressed often through the use of creativity techniques (such as the knowledge hub or the design thinking technique (Cravotta et al. 2017; 2018a). 
For example, a knowledge hub involves the process of first discussing customers' problems with one group of employees (e.g., sales), while another group (e.g. the developers) is taking notes and writing down possible solutions. In a second step, both groups change and now the sales department listens to the suggested solution. Afterwards there will be a mixed discussion. The core of design thinking is the attempt to generate a problem-solving and creation process from an interdisciplinary point of view using a defined method (Brown and Wyatt 2010, 31). The approach is based on the insight that typical problems in the economy and society have become so complex that (mono) disciplinary and (mono) causal heuristics are no longer sufficient to arrive at acceptable solutions in a timely manner. A peculiarity with respect to the origin of design thinking from design is that much more than just ideas play a role. Rather, design thinking is about solving particularly fuzzy and complex problems that can therefore be addressed by a variety of ideas (Cravotta et al. 2018a). From a methodological point of view, the design thinking method is based on a change in the observer's perspective and proceeds in six steps (Müller and Thoring 2012, 3):

1. Understanding the problem (Understand)

2. Observing the user environment / problem context (Observe)

3. Perception from the user / customer / micro-theory of the problem (Point of view),

4. Generate ideas with creative techniques (Ideas),

5. Create prototypes (Prototype), and

6. Improve them (Test).

For a simple reason, products resulting from such intensive approaches such as design thinking and knowledge hub related to the spinnovation approach are not in danger of being replaced by simple mass customization, which can be significantly expanded by Industry 4.0: the focus on 
one from the beginning complex problem prevents a simple imitation by competitors from taking place. It is not so much the customer and the market, which is kept secret here, as the problem solution, which is hidden because it is personalized. This can be illustrated, in particular, by an example of a consulting service product. A consulting service product is the better accepted the better it can be tailored to the needs of the customer. A product design that uses such a specialized solution instead of a recurring blueprint will be able to address complex special problems of a customer. The challenge, of course, is to have enough standardized components to be able to offer the result of such a process at competitive prices.

\subsection{Dimension digital brand management}

The changes triggered by digitalization in the form of the increasing (or at least additional) virtualization of the human range of motion creates also a new framework and sets new conditions for brand management in family businesses. The old-fashioned principles that have since been known and observed in brand management such as the credibility and relevance of the brand among consumers and the distinctive character of the brand compared with others that is, the natural laws of Hermes (Hermes 2008, 284) - are therefore not enough anymore to position the brand of a family firm in the target audience. This becomes transparent when taking into account that together with the arising customer related individualization at the same time a fragmentation of markets arises. The question is then what a brand means when customers are not served by a product any more but rather by an individually tailored complex solution. To react to digitalization, family businesses need therefore to consider further basic principles that take into account the peculiarities of the virtual space. In particular, this involves the question how in particular German family firms make sure that they are at the same time acting secretly and hidden and are easily and meaningfully found in the world of the internet. Cravotta 
et al. (2018b) propose three further basic principles, the so-called three $C^{\prime} s$ (Cravotta et al. $2018 \mathrm{~b}, 3)$ to solve this problem. A brand must be where the target group is and connect with it in the virtual space (connectivity). This also requires finding hidden champions on the internet. At the same time, the maximization of awareness of the relevant target groups on the one hand and the minimization of awareness among competitors should also be transferred to the digital age. For this purpose, all online and offline based activities or experiences are to be coordinated with each other in the sense of a holistic brand management (complementarity). In particular, it must be ensured that the target group recognizes the outstanding benefits of the solutions offered by the family-owned companies through the interaction of online and offline components, while competitors receive only fragments online and, as a rule, no information offline. Digital brands also become a substitute for orientation and reduce the need for information and protection. Digital brands must therefore be easy to use (complexity reduction). Above all the importance of an overarching digital brand increases. In an era of $n$ to $n$ relationships in which customers significantly determine which firm they choose and with which firm they identify it is not sufficient to provide a message by the brand that describes the firm. Instead it is rather necessary to extend the meaning of a brand to the entire network in which the family firm operates.

Depending on the strategic goals which are pursued by a family business, various instruments and methods can be used in (digital) brand management. If, for example, the establishment of a targeted brand communication with the customer and/or the promotion of the brand, the company can use tools such as Live Content or influencer marketing. In the context of influencer marketing, a company tries to involve opinion makers and thus people with reputation, influence and reach into their online brand communication. If the family business 
tries to create brand loyalty, mass customization and social media marketing can be used. Webdata analytics can be applied to verify whether these activities rendered the impact that was previously intended. A good overview of applicable tools and methods in (digital) brand management is given in the work of Cravotta et al. (2018b).

\subsection{Dimension digitalization in production \& value creation}

A phenomenon that accompanies digitalization in production and the value chain (see also Grottke and Boll 2018) is that there is an increasing intermeshing of functional areas with regard to human co-operation. Increasingly, it is no longer possible to think in functional departments and thus in silos (as would be the case, for example, in a division in the sense of Gutenberg's form, for example, in separate purchasing, production and sales departments). Instead, departments will interact continuously. For example, it is no longer just the individual workplace that is optimized, but teams optimize on a holistic level, teams that are made up of different departments and formed across departments. This results in carving out holistic views on processes and in meshing control loops. The advantage of such holistic views is that there is less danger of missing the needs of the market, because the development department has the perspective of the market right from the beginning. The advantages of such meshing are very easy to illustrate considering that there are in principle many development paths in product development which makes it difficult to sort out the right one. Here, information of the distribution on which development paths might be probably preferred by the customer can lead to a minimization of the risk of undesirable developments. The challenge for family firms is to create the holistic view within teams on the one hand and to adapt the production systems continuously without loosing too much flexibility. In a certain way with digital factories what comes in new is the difference between principally unlimited human flexibility and production 
system flexibility which is always limited to those options that have been previously thought of.

Furthermore, use of platforms to optimize the value chain can be made. An advantage of family businesses can lie in years of trusting cooperations with their customers and suppliers, which now allows for realizing corresponding efficiency advantages by a partial mutual disclosure of data and thus better responsiveness that allows for realizing e.g. advantages of optimization that becomes possible by making use of artificial intelligence when tracking for product errors during the entire supply chain (Grottke et al. 2016b). It should be noted, however, that the study by Lichtner and Kinkel (2018) so far suggests that family businesses, as a rule, do not disclose data beyond their own company. For example, only $15 \%$ in the study use an open IT platform. However, individual cases of such a cooperation with advantages for both partners are listed in the study by Grottke and Boll (2018). A third aspect is that there is an increasing merging of IT and subject domains, which create new cross-training occupations (Olsen 2018).

\subsection{Dimension Integration and collaboration}

Two other major changing determinants for family businesses are that on the one hand, that speed becomes more important compared to accuracy and quality, and on the other hand, that more and more investments are software-like, with high initial investment and marginal costs close to zero (Anderson 2012).

Both determinants have in common that they push the individual family firm into stronger cooperation relationships. The aforementioned German family firm Rieber, for example, was only able to realize its solution by making use of a network of strategic external partners it had neither known nor worked with before (Purps-Pardigol and Kehren 2018). As a result, speed can only be increased if, on the one hand, the focus is maintained and, on the other hand, 
business is passed on to cooperation partners when it arises beyond the own focus which stands in contrast to the beforehand existing "my home, my castle" policy of many family firms in Germany. In addition, marginal costs close to zero suggest that as many users as possible are necessary after having incurred a certain investment, which seems particularly possible if the number of users can be increased by leaps and bounds through cooperation. All this involves a major shift in the attitude of family firms, because this involves that family firms need to become well-known with their solutions rapidly among potential customers instead of keeping them rather known to current customers but secret beyond.

To our knowledge, family businesses, in particular cloud providers, are experimenting with a disclosure of knowledge previously unknown to family businesses for cooperation partners with whom they have already been working for many years. However, there is still a certain reservation against cooperation in the area. Whether the family businesses among companies succeed in realizing the advantages of cooperation will have to be seen. While some firms, particularly in the cloud service area cooperate such as, for example, the German hidden champion Phoenixcontact, others are still reluctant to cooperate.

\section{Summary, conclusion and outlook}

Summarizing the insights previously outlined in a nutshell, we find that digitalization offers opportunities and challenges for family businesses in general and for German family firms in particular. The challenges are to be seen in the fact that certain aspects of a family business, such as the question of secrecy or dedication of owners need to be changed and rebalanced. No family business can really escape these challenges. The most important message is therefore probably that there are suitable opportunities to set up as a family business with its characteristics to be future-oriented and well-prepared also in the age of digitalization. 
In particular in the arising six key dimensions of digitalization it is outlined how German family businesses can respond to the changes driven by digitalization. All six dimensions have in common that they are more of a strategic nature, which must be implemented in a respective family business and which need to be adapted to the individual circumstances prevailing in the respective family business. In addition, implementation also brings structural changes in organizations. As a result, the affected family business must be prepared for long-term changes that also affect day-to-day business. This requires a rethinking not only of the managers of family businesses, but especially of the owner families, because they significantly influence the company's development and are responsible for the stability of their family business (see again Haftlmeier-Seiffert and Cravotta 2018). However, the authors' experience shows that a rethinking of family businesses, whether in Germany or in Europe, sometimes is hindered by hurdles among decision-makers in family firms. The family owners often stick to old solutions; they are more resistant to structural changes and change processes.

However, on the other hand, it might be an important advantage in the upcoming digital transformation for family businesses that most of the ownership is in the hands of a family or a small group of owners. The great opportunity that results from this is precisely that no consideration has to be given to the information needs, fashions and trends of an anonymous capital market (see also Grottke 2011, 295-298). The concomitant freedom to focus solely on the economically and entrepreneurially meaningful represents an excellent prerequisite for the use of the new possibilities of digitalization: "The innovative strength and entrepreneurial thinking of the German middle class [...] are excellent prerequisites [...] for an active driver role in reference to Industry 4.0 [...]." (BMWi 2015, 23). 
Advantages, for example, are likely to come from the fact that family businesses, since they are less under pressure to implement available short-term cost-cutting measures in the form of employee lay-offs with available automation options, must focus less on cutting back on employees than on an even greater qualification of these employees and the increase of their productivity with the help of new technical possibilities. This is all the more an opportunity, as it is economically costly to accumulate the necessary factory-specific experience.

Family businesses are also characterized by their close relationships with their customers - they are problem solvers. Especially their customer orientation is certainly another important advantage to find one's own way through the digitalization wave. Thus, the changes can also be addressed together with the main customers. Customer Co-Creation, Joint product development or the establishments of a joint venture are conceivable examples of how cooperation can be implemented.

Finally, the high level of employee loyalty in family businesses could be seen as an advantage for the implementation of digital business models.

It should be noted as a limitation that in the article only the author's impressions of the current interaction between family businesses and digitalization, complemented with the scarce existing empirical evidence on digitalization in family firms was reproduced. A limitation hereby remains that no complete description of the effects of digitalization on German family businesses was sought or could have been sought. Moreover, the comparability of the results for family businesses in other countries is limited. However, this opens space for further research and could sharpen the authors' impressions of the peculiarities and success factors of digital transformation in family businesses in practice. A comparison between German and Spanish family businesses would be inspiring particularly in the early phase of digitalization in 
family businesses in which much is unclear yet. So far this has received little attention in international family business research.

Overall, family businesses in Germany remain a highly exciting field of research during and after the digital transformation. In particular the tensions identified in the six chapters that demonstrate that it is not clear yet in which direction family firms should develop provide interesting empirical questions. This is for the example the case with the question to which degree hierarchy will be still typical for family firms ore the question to which degree secrecy will be observed in future. It will only be clear in a few years' time whether and which family businesses will have a future after the digital transformation and how they would have to compete or cooperate in the future.

\section{References}

Ahrens, Thomas. 1997. "Talking accounting: an ethnography of management knowledge in British and German brewers." Accounting, Organizations and Society 22 (7): 617-637.

Anderson, Chris. 2012. Makers: the new industrial revolution. New York: Crown Business.

Becker, Wolfgang, Michaela Staffel, and Patrick Ulrich. 2008. Mittelstand und Mittelstandsforschung. Bamberger Betriebswirtschaftliche Beiträge 153.

BMWi. 2015. Erschließen der Potenziale der Anwendung von „Industrie 4.0“ im Mittelstand (short version). In Erschließen der Potenziale der Anwendung von Industrie 4.0 im Mittelstand, edited by Jürgen Bischoff. Accessed September 12, 2016.

http://www.bmwi.de/BMWi/Redaktion/PDF/Publikationen/Studien/erschliessen-der-potenzialeder-anwendung-von-industrie-4-0-im-mittelstandkurzfassung,property=pdf,bereich=bmwi2012, sprache $=\mathrm{de}, \mathrm{rwb}=$ true.pdf.

Borg, Rainer, and Tom Hill. 2018. Agile Kollaboration - zukünftige Möglichkeiten organisationaler Zusammenarbeit bei der Digitalisierung. In Tagungsband 1. Tagung für Familienunternehmen, Teilband 3: Digitalisierung in Familienunternehmen, Tagungsband, edited by EQUA-Stiftung, 21-25.

Brown, Tim, and Jocelyn Wyatt. 2010. "Design Thinking for Social Innovation.” Stanford Social Innovation Review (Winter 2010):31-35. 
Christensen, Clayton M. 1997. The Innovator's Dilemma - When New Technologies Cause Great Firms to Fail. Harvard: Harvard Business School Press.

Cravotta, Sven. 2014. "Eigentümer und Fremdmanager als Team in der Geschäftsleitung von Familienunternehmen - Indirekte Kontrollbeziehungen in Mischgeschäftsführungen.” In EQUASchriftenreihe, edited by EQUA-Stiftung. Heft 13/2014. Bonn.

Cravotta, Sven. 2013. "Die gemischte Geschäftsführung als Managementstruktur langlebiger Familienunternehmen.” In Wittener Schriften zu Familienunternehmen, Band 12, edited by Arist von Schlippe, and Tom A. Rüsen. Wittener Institut für Familienunternehmen (WIFU) an der Universität Witten/Herdecke. Göttingen: Vandenhoeck \& Ruprecht.

Cravotta, Sven. 2010. Managementstrukturen in älteren Familienunternehmen (verarbeitendes Gewerbe). WIFU Working Paper Series Nr. 6, Universität Witten/Herdecke. Accessed August 2, 2018. http://www.wifu.de/wp-content/uploads/downloads/2011/03/WIFU-WP-Series-Nr.6_Cravotta.pdf.

Cravotta, Sven, Markus Grottke, and Andreas König. 2018a. "Neue Geschäftsmodelle für Familienunternehmen - Identifikation, Evaluation und Optimierung mit Hilfe von Lean StartupAnsatz und Design Thinking (Teil II)." FuS - Zeitschrift für Familienunternehmen und Stiftungen. Recht, Management, Familie und Vermögen Heft 1/2018:10-14.

Cravotta, Sven, Erich Posselt and Philipp Steiff. 2018b. Instrumente und Methoden der digitalen Markenführung. Working Paper. SRH Hochschule Heidelberg, Campus Calw.

Cravotta, Sven, Markus Grottke, and Andreas König. 2017. "Neue Geschäftsmodelle für Familienunternehmen - Identifikation, Evaluation und Optimierung mit Hilfe von Lean StartupAnsatz und Design Thinking (Teil I)." FuS - Zeitschrift für Familienunternehmen und Stiftungen. Recht, Management, Familie und Vermögen Heft 6:196-199.

Demary, Vera, Barbara Engels, Klaus-Heiner Röhl, and Christian Rusche. 2016. Digitalisierung und Mittelstand, edited by Institut der deutschen Wirtschaft Köln.

Europäische Kommission. 2016. Annual Report on European SMEs 2015/2016 - SME Recovery Continues, Accessed November 27, 2016. https://ec.europa.eu/growth/smes/business-friendlyenvironment/performance-review-2016_en.

Gray, Sidney .J. 1988. 'Towards a theory of cultural influence on the development of accounting systems internationally.' Abacus 24 (1): 1-15.

Grottke, Markus. 2011. Ordnungspolitische Wirkungen des elektronischen Bundesanzeigers und einer Einführung der internationalen Rechnungslegung für nicht kapitalmarktorientierte Unternehmen (IFRS for SMEs). Zeitschrift für Wirtschaftspolitik 60 (3): 285-314. 
Grottke, Markus, Johann V. Löffelmann, Thomas Späth, and Felix Haendel. 2016a. "Financial statement's disclosure in the electronic federal gazette and proprietary concerns." Revista de Ciências Empresariais e Jurídicas 27:127-176.

Grottke, Markus, Obermaier, Robert, and Stefan Walter. 2016b. "Qualitätscontrolling: Mit Internet of Things-Technologie die Lieferantenqualität besser steuern und damit Kosten senken.” In Einkaufscontrolling Instrumente und Kennzahlen für einen höheren Wertbeitrag des Einkaufs, Sonderheft des Controlling-Berater 2016, edited by Klein, Andreas, and Peter Schentler, 137-154. Freiburg: Haufe Verlag.

Grottke, Markus, and Felix Boll. 2018. Unternehmerische Gestaltungsoptionen im Rahmen der Digitalisierung- Einsichten aus einer Interviewstudie mit Entscheidungsträgern im Nordschwarzwald, unveröffentlichte Studie der SRH Heidelberg, Campus Calw and IHK Nordschwarzwald.

Haftlmeier-Seiffert, Rena, and Sven Cravotta. 2018. Das Chamäleon-Modell als Erklärungsmuster für die Organisationsstrukturen von Unternehmerfamilien, Arbeitspapier, EQUA-Stiftung München and SRH Hochschule Heidelberg, Campus Calw.

Hermes, Oliver. 2008. "Die Naturgesetze der Markenführung im Handel." In Retail Business in Deutschland, Perspektiven, Strategien, Erfolgsmuster, 2. edition, edited by Hans-Christian Riekhof, 275-299. Wiesbaden: Gabler.

Hiebl, Martin R.W. 2012. "Familienunternehmen: Bedeutung, Ausprägungsformen und Besonderheiten." Wirtschaftswissenschaftliches Studium 41(4): 184-188.

Legner, Christine, Torsten Eymann, Thomas Hess, Christian Matt, Tilo Böhmann, Paul Drews, Alexander Mädche, Nils Urbach, and Frederik Ahlemann. 2017. "Digitalization: opportunity and challenge for the business and information systems engineering community." Business \& information systems engineering 59 (4): 301-308.

Lichtner, Ralph, and Stephan Kinkel. 2018. "Digitally networked innovation work of German pioneering companies: cautious transformation." Working paper presented at The ISPIM Innovation Conference - Innovation, The Name of The Game, Stockholm, Sweden, June 17-20.

Müller, Roland M., and Katja Thoring. 2012. "Design Thinking vs. Lean Startup: A comparison of two user-driven innovation strategies." Leading Innovation through Design 151:1-12.

Nobes, Chris. 1998. "Towards a general model of the reasons for international differences in financial Reporting.” Abacus 34 (2): 162-187.

Obermaier, Robert. 2018. "Digitalisierung und Familienunternehmen." In 1. Tagung für Familienunternehmen, Teilband 3: Digitalisierung in Familienunternehmen, Tagungsband, edited by EQUA-Stiftung, 7-12. 
Purps-Pardigol, Sebastian, and Henrik Kehren. 2018. Digitalisieren mit Hirn. Wie Führungskräfte ihre Mitarbeiter für den Wandel gewinnen. Campus Verlag. Frankfurt/New York.

Olsen, Jörg. 2018. "Digitalisierung aus der Sicht von Maschinen und Entscheidungsträgern." In 1. Tagung für Familienunternehmen, Teilband 3:Digitalisierung in Familienunternehmen, Tagungsband, edited by EQUA-Stiftung, 30-35.

Ries, Eric. 2011. The Lean Startup: how today's entrepreneurs use continuous innovation to create radically successful businesses. New York: Crown Business.

Schlippe, Arist von, Almute Nischak, and Mohammed El Hachimi. 2008. "Familienunternehmen verstehen." In Familienunternehmen verstehen - Gründer, Gesellschafter und Generationen, edited by Arist von Schlippe, Almute Nischak, and Mohammed El Hachimi, 19-29, Göttingen: Vandenhoeck \& Ruprecht.

Simon, Hermann. 2007. Hidden Champions des 21. Jahrhunderts: Die Erfolgsstrategien unbekannter Weltmarktführer, 1. edition., Frankfurt [u.a]: Campus Verlag.

Stiftung Familienunternehmen. 2017. Die volkswirtschaftliche Bedeutung der Familienunternehmen, implemented by ZEW and ifm Mannheim, Accessed Juli 28, 2018. https://www.familienunternehmen.de/media/public/pdf/publikationenstudien/studien/Volkswirtschaftliche-Bedeutung_Studie_Stiftung_Familienunternehmen.pdf.

Venter, Karlheinz, and Kerstin Friedrich. 2017. Spinnovation. Intelligent spezialisieren, kraftvoll innovieren, Alleinstellung neu entwickeln. Das unverzichtbare Arbeitsbuch für Strategie und Alleinstellung, München: Vahlen.

Wittener Institut für Familienunternehmen. 2018. Definition Familienunternehmen. Accessed August 2, 2018. http://www.wifu.de/forschung/definitionen/familienunternehmen/. 